\title{
Single extremely large loose body in olecranon fossa in a young patient
}

\author{
Ilias Galanopoulos, ${ }^{1}$ Neil Ashwood, ${ }^{2}$ Quentin Fogg, ${ }^{3}$ Babis Karagkevrekis ${ }^{2}$
}

${ }^{1}$ Department of Trauma and Orthopaedics, St George's Hospital, London, UK ${ }^{2}$ Department of Trauma and Orthopaedics, Queen's Hospital, Burton-on-Trent, UK ${ }^{3}$ Laboratory of Human Anatomy, University of Glasgow, Glasgow, UK

\section{Correspondence to} llias Galanopoulos, galanop.ilias@gmail.com

\section{DESCRIPTION}

A 19-year-old female patient injured her right elbow following a fall off her bike 5 years ago and had gradually developed pain at the extremes of motion with mild restriction in the range of motion and minimal functional compromise. Three years later she had another fall and presented with moderate swelling and a mild loss of elbow extension. During the last 2 years, she had occasional pain and clicking sensation but her symptoms usually settle after a few days' rest and anti-inflammatory medication.
Plain radiographs revealed a single large loose body located in the olecranon fossa measured about $18 \mathrm{~mm}$ diameter (figure 1), which has also been confirmed by CT scan (figure 2) and MRI (figure 3). There is also a small area of cortical irregularity at the posterior aspect of the lower end of humerus close to the radiocapitellar joint.

Currently, her ROM remains mildly restricted (range $10^{\circ}-140^{\circ}$ ) with normal pronation and supination of the forearm. There seems to be a mechanical block to extension, but her overall function and level of activities remain within normal limits.

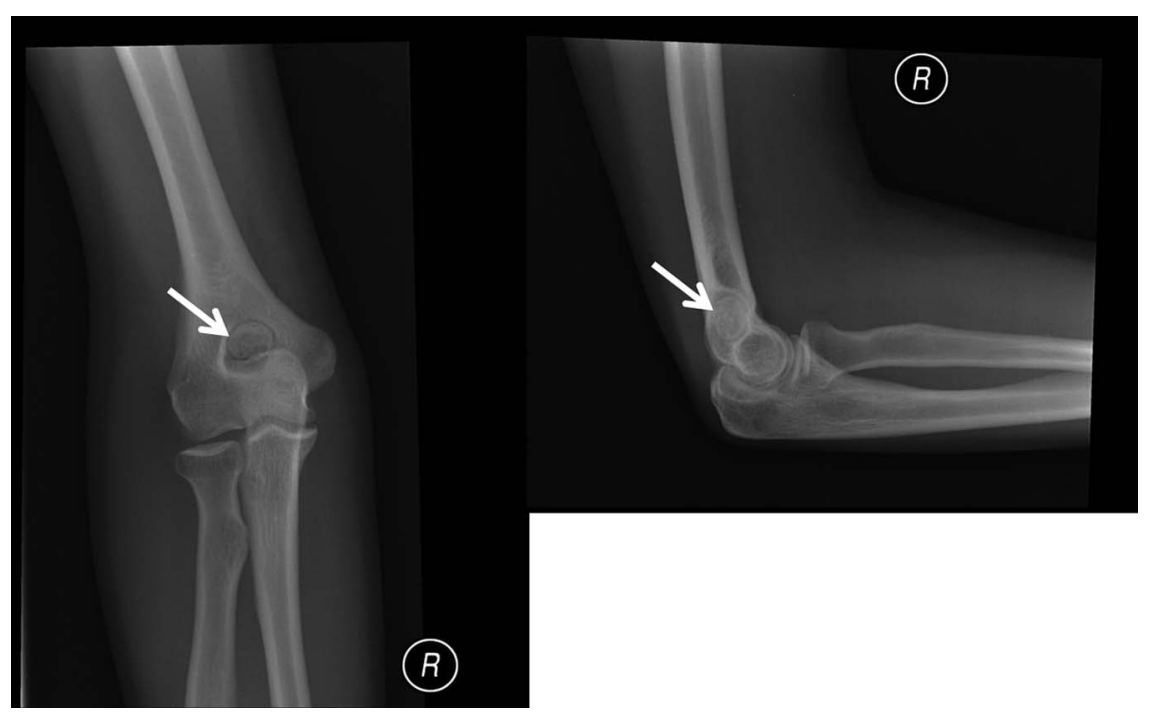

Figure 1 Plain radiographs showing a single large loose body seated in the olecranon fossa (arrow).

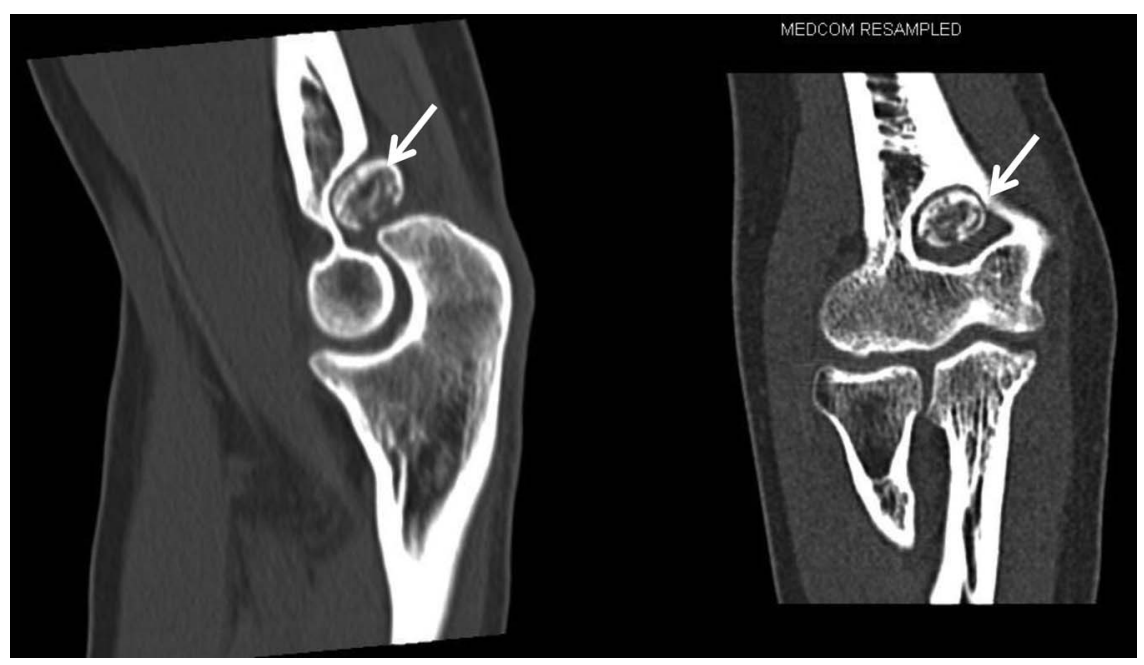

To cite: Galanopoulos I, Ashwood N, Fogg Q, et al. BMJ Case Rep Published online: [please include Day Month Year] doi:10.1136/ bcr-2013-010151

Figure 2 CT scan (sagittal, axial and coronal cuts) showing the same round loose body in more detail (arrow). 


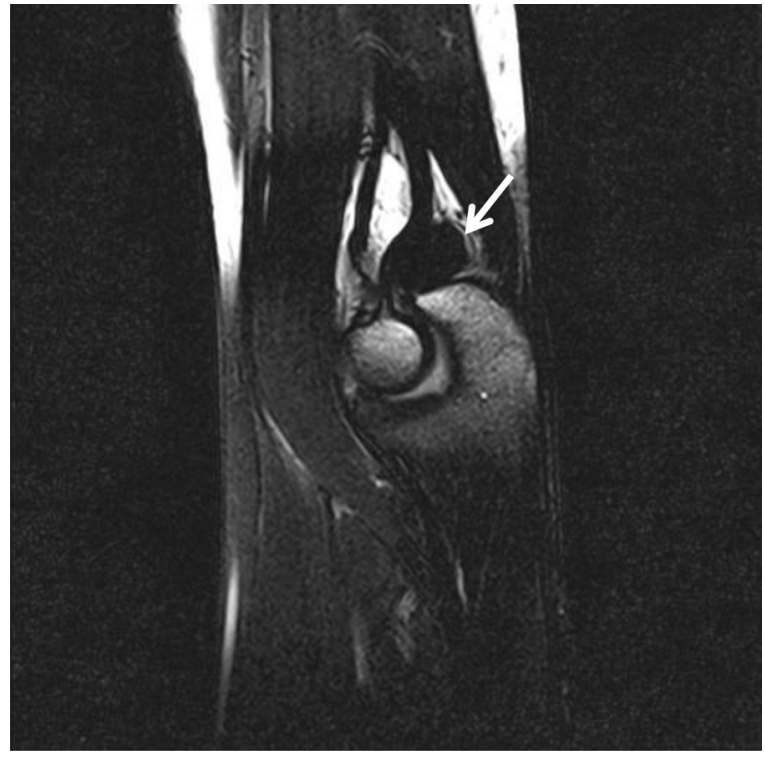

Figure 3 MRI (sagittal view) showing the large loose body (arrow).

Acquired loose bodies in the elbow joint originate from four main sources of underlying pathology: post-traumatic, degenerative, osteochondritis dissecans and synovial chondromatosis. ${ }^{1}$ Typically, patients complain of pain with snapping and clicking in the joint. ${ }^{2}$ Blocking of elbow extension is more common ${ }^{3}$ and is caused by deposition of chondral fragments in the olecranon fossa. Elbow arthroscopy is the treatment modality of choice for removal of cartilaginous loose bodies that become symptomatic. $^{4}$

\section{Learning points}

Loose bodies within the elbow joint are quite rare in young patients and usually remain asymptomatic for prolonged periods.

- They can gradually increase in size and cause intermittent mechanical symptoms.

- Symptomatic loose bodies can be removed either arthroscopically or by open surgery.

Contributors All authors have made a significant contribution to the preparation of the manuscript including clinical management of the patient, collection of the data, writing and editing of the final manuscript.

Competing interests None.

Patient consent Obtained.

Provenance and peer review Not commissioned; externally peer reviewed.

\section{REFERENCES}

1 Boe S. Arthroscopy of the elbow. Diagnosis and extraction of loose bodies. Acta Orthop Scand 1986;57:52-3.

2 Bell MS. Loose bodies in the elbow. Br J Surg 1975;62:921-4.

3 Kamineni S, O' Driscoll SW, Morrey BF. Synovial osteochondromatosis of the elbow. $J$ Bone Joint Surg Br 2002;84:961-6.

4 O' Driscoll SW, Morrey BF. Arthroscopy of the elbow. Diagnostic and therapeutic benefits and hazards. J Bone Joint Surg Am 1992;74A:84-94.

Copyright 2013 BMJ Publishing Group. All rights reserved. For permission to reuse any of this content visit

http://group.bmj.com/group/rights-licensing/permissions.

BMJ Case Report Fellows may re-use this article for personal use and teaching without any further permission.

Become a Fellow of BMJ Case Reports today and you can:

- Submit as many cases as you like

- Enjoy fast sympathetic peer review and rapid publication of accepted articles

- Access all the published articles

- Re-use any of the published material for personal use and teaching without further permission

For information on Institutional Fellowships contact consortiasales@bmjgroup.com

Visit casereports.bmj.com for more articles like this and to become a Fellow 